\title{
Contribution of Vertical Farms to Increase the Overall Energy Efficiency of Urban Agglomerations
}

\author{
Podmirseg Daniel \\ Institute for Buildings and Energy Technical University, Graz, Austria \\ Email: daniel@podmirseg.com
}

Received December 2013

\section{Abstract}

The 21st century keeps huge challenges for the system "city". Shortage of resources and world population growth forces architects to think in spaces with increasingly more structural linkages. No era has shaped the system of a city like the oil age did. Its grown structures are dependent from cheap and easy to produce petroleum. The postmodern city, facing the end of cheap and abundant oil, is now dependent from this finite resource. To minimize the dependency from hydrocarbon energy it is necessary to increase urban density, to switch to renewable energy production and to create new spaces for multifunctional purposes. An essential problem of urban agglomeration, though, is the fact that distances between food production and consumption have increased drastically in the last fifty years. Cheap oil made it possible to implement a global food transportation network and it also supported intensive monocultural food production. Today's food no more gets bought from local markets, but from labels. Its value is dependent from the brand-image, represented from the tertiary sector. The end of cheap fossil fuels carries a huge potential for architects and urban planners-we can move away from representing abstract, non-spatial processes and identities but creating spaces for dynamic local interactions. A promising typus for this might be the Vertical Farm.

\section{Keywords}

Vertical Farming; Energy Production; Energy Efficiency; Water Security

\section{Biocapacity-Peak Oil}

In the last fifty years world population growth entailed to a massive growth of urban agglomerations, not just in terms of density but also in land consumption. This development was also made possible through the production of massive amounts of petrochemical products. Low oil prices and easy production circumstances not just made these sturcural changes of cities possible, but by irony it made nowadays cities dependent on this situation. This fact is a huge challenge for the city of tomorrow.

"Peak oil" [1] and the upcoming explosion of prices of fossil fuels make it necessary to reconstruct and reconfigure the system "city”. 
Massive land use and easy-to-get oil also lead to actual systems of food production [2], especially in industrialized and emerging countries: Food no longer gets produced where it gets consumed [3]. A global food network emerged nowadays in mega cities is completely dependent and couldn't supply themselves with daily needed edible biomass.

The question whether the biocapacity of the earth is big enough to feed world population of the next generations actually is intensively discussed between scientists and researchers [4] [5]. Complex calculation models show different results and methodologically strongly different approaches make results even more difficult to compare.

But what we know is that a third of our earth's surface is covered with land mass. And a third of it has the capacity to produce food [6]. This area, globally, is unevenly allocated and the dependency of global food transportation networks is inherent. This view on the problem of food security of urban agglomerations demonstrates the challenge to increase the overall energy efficiency of cities, especially in food production.

\section{What Is a Vertical Farm?}

The idea of food production in city indeed is not new. Glass- and greenhouses, courtyard-gardening, rooftop gardens and winter gardens are common elements of cities. On an inflationary way low- and high-tech experiments get published for years now; with very little potential of relevant energy production (directly or via biomass). But a closer look to these enterprises envision, beside the economic advantages (which in most cases can get ignored), a unique side-effect: a new spatialization of direct interdependencies between different interests and professions [7] [8].

The Vertical Farm, although, on an industrial level, promises the biggest efficiency in terms of biomass-production $/ \mathrm{m}^{2}$ [9] [10].

Cultivation area gets STACKED, CONDITIONED and URBANIZED: These three headwords outline the principle of Vertical urban Farms.

\section{Stacking}

Actually every inhabitant, if he's an omnivore, needs ca. $2300 \mathrm{~m}^{2}$ [11] on cultivation area to produce enough fruit, vegetable, wheat, oil seeds, semi luxury food, milk, meat and fish, but also feed for animal husbandry.

Research results show that food production (especially vegetable and fruit) in a controlled environment can radically reduce the needed cultivation area (up to thirty times) and the ecological footprint in food production [12].

This allows an intensification of biological or alternative food production like permaculture on areas Vertical Farms are compensating [13]. Giving agricultural areas, damaged by conventional cultivation practises, back to nature, soil can be regenerated or reforestation is thinkable.

\section{Conditioning}

In a conditioned stacked greenhouse edible biomass production can be guaranteed 365/24hours a day [14]. This excludes food losses and crop reductions through droughts, hail and other weather conditions. Technologies like hydroponics and aeroponics obviate the use of herbicides, fungicides and fertilizers [15]. Another advantage offers the closed water cycle which guarantees a drastic reduction of water use in food production and enables the possibility of water recycling and the reuse of grey water [16].

Simulation- and calculation models although also show that the provision of the necessary light intensity to support photosynthesis leads to relevant energy consumption [17].

\section{Urbanization}

Actual system borders of the basic needs-field "nutrition" only can be analysed on a global scale [18]. Material flow analysis [19] of this basic needs-field is more and more the primary subject of different scientific research works, mostly compared with a $\mathrm{CO}_{2}$-balance of different food products. These results envision an enormous potential to increase the overall energy efficiency of urban agglomerations by implementing Vertical Farms.

Numerous mega cities import their food up to $80 \%$ not from the surrounding of the city border or from the country itself, but from foreign countries [20]. Food miles as a consequence are related to massive energy con- 
sumption (through fossil fuels) and lead to drastic $\mathrm{CO}_{2}$-output [21].

Furthermore food miles lead to direct and indirect costs on a social and economic level, and on the environment. This situation is one of the most important reasons why the ecological food footprint [22] multiplies the per capita food production footprint per five times [23] — up to 15,000 $\mathrm{m}^{2}$.

Especially for architects and urban planners these circumstances offer an opportunity to examine and develop the typus of the Vertical Farm. The functional system borders of conventional agriculture can be described as follows [24]:

Seeds, fertilizers, pesticides and herbicides have to be produced before they reach the cultivation area via transport. After an energy intense cultivation and animal husbandry-period products, again through transport, get provided or to food processing industries or wholesale trade systems (storage). In this moment huge amounts of energy are needed for cooling systems, storage, packaging materials and packaging processes, before, again via transport, food products get distributed to markets, households or again to decentralized storages [25].

These processes have to be closed in a system in Vertical Farms. Production of nutrition substances, animal husbandry and edible biomass cultivation, food processing and waste management (eventually for energy production), water management and implementation of installation technology (hvac) and lighting find place on a local scale. This reimplementation of local social and economic interdependencies in this context can be read as the biggest potential of Vertical Farms.

Material flow analysis-the comparison from conventional agriculture and the Vertical Farm is the nucleus of the dissertation. The essential question comes up is: To what extend can the Vertical Farm be a contribution to increase the overall energy efficiency [26] of urban agglomerations? What is the difference between the saved energy through shrinking of system borders of food production [27] on a local level and the energy needed to run a Vertical Farm?

Especially for the Symposium questions in this context should change their focus on spatial potential and qualities to enable discussions on architectonic and urbanistic levels [28].

What are the potential spatial intersections between the production entity and the public space? Which new concepts of public and semi-public spaces can be envisioned by implementing hybrid types (Vertical FarmHousing, Vertical Farm-Shopping Malls, Hyperbuildings $\left.{ }^{*}\right)$ ? Which additional functions only can lead to a hybridization (market, trade, multifunctional horizontal/vertical public spaces, parks, spaces for social gathering)?

\section{References}

[1] (2012) Oil\&Gas2_Campbell update 2012.xlsx

[2] (2008) The Atlas of Food, Millstone.

[3] (2008) The Atlas of Food, Millstone.

[4] (2000) Global Agro-Ecological Zones Assessment, IIASA.

[5] (2010) Towards the Third Green Revolution, Harald von Witzke.

[6] (2009) World Resource Outlook to 2050, Jette Bruinsma.

[7] (2006) The Power of Community, How Cuba Survived Peak Oil.

[8] (1996) Local Food Systems and Sustainable Communities, Feenstra.

[9] (2010) The Vertical Farm, Dickson Despommier.

[10] (2004) Advanced Life Support Baseline Values and Assumptions Document, NASA.

[11] (2012) Tonnen für die Tonne, WWF und Harald von Witzke.

[12] (2012) Market Analysis for Terrestrial Application of Advanced Bio-Regenerative Modules: Prospects for Vertical Farms, Chirantan Banerjee.

[13] (2009) Farm of the future, produced by Tim Green and Rebecca Hosking, BBC.

[14] (2010) The Vertical Farm, Dickson Despommier.

[15] (2010) The Vertical Farm, Dickson Despommier.

[16] (2004) NASA Advanced Life Support Baseline Values.

[17] (2012) Market Analysis for Terrestrial Application of Advanced Bio-Regenerative Modules: Prospects for Vertical Farms, Chirantan Banerjee.

[18] (2005) Umweltauswirkungen von Ernährung-Stoffstromanalysen und Szenarien, Wiegmann/Eberle/Fritsche/Hünecke. 
[19] (2008) $\mathrm{CO}_{2}$-Bilanz der Tomatenproduktion: Analyse acht verschiedener Produktionssysteme in Österreich, Spanien und Italien, Theurl.

[20] (2002) City Limits, Livingston.

[21] (2005) DEFRA - Department of Environment Food and Rural Affairs, Validity of Food Miles UK.

[22] (2005) DEFRA - Department of Environment Food and Rural Affairs, Validity of Food Miles UK.

[23] (2009) Time to Eat the Dog? Robert and Brenda Vale.

[24] (2005) Umweltauswirkungen von Ernährung-Stoffstromanalysen und Szenarien, Wiegmann/Eberle/Frische/Hünecke.

[25] (2005) Umweltauswirkungen von Ernährung-Stoffstromanalysen und Szenarien, Wiegmann/Eberle/Frische/Hünecke.

[26] (2010) The Vertical Farm, Dickson Despommier.

[27] (2000) Ressourceneffizienz in der Aktivität Ernährung, Mireille Chloé, Jeanne Rachel Faist, ETH Zürich.

[28] (2012) DIO NERO, from Citigroup to Citicrop Headquarter, Exhibition, IMDP. 